\title{
Size of nesting female Broad-snouted Caimans (Caiman latirostris Daudin 1802)
}

\author{
P. M. L. Leiva ${ }^{a, b}$, M. S. Simoncini ${ }^{a, b}$, T. C. G. Portelinha ${ }^{a, c, d}$, A. Larriera Le $^{b, e}$ \\ and C. I. Piña $a^{a, b, f *}$ \\ ${ }^{a}$ Centro de Investigaciones Científicas y Transferencia de Tecnología a la Producción - CICyTTP, Consejo Nacional de \\ Investigaciones Científicas y Técnicas - CICyTTP, Dr. Materi y España, Diamante, Entre Ríos, Argentina \\ 'Proyecto Yacaré, Laboratorio de Zoología Aplicada: Anexo Vertebrados, Facultad de Humanidades y Ciencias - FHUC, \\ Universidad Nacional del Litoral - UNL, Aristóbulo del Valle 8700, Santa Fe, Santa Fe, Argentina \\ ${ }^{c}$ Curso de Engenharia Ambiental, Universidade Federal do Tocantins - UFT, Avenida NS-15, Quadra 109 Norte, \\ CEP 77001-090, Palmas, TO, Brasil

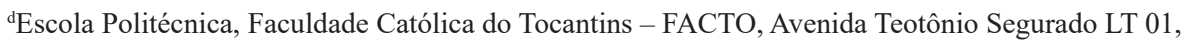 \\ Bairro Centro Quadra 1402 Sul, CEP 77061-002, Palmas, TO, Brasil

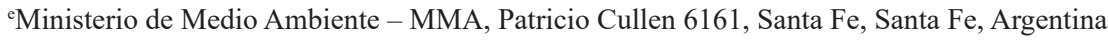 \\ ${ }_{\mathrm{f} F a c u l t a d}$ de Ciencia y Tecnología - FCyT, Universidad Autónoma de Entre Ríos - UADER, Dr. Materi y España, \\ Diamante, Entre Ríos, Argentina \\ *e-mail: cidcarlos@infoaire.com.ar
}

Received: June 1, 2017 - Accepted: September 14, 2017 - Distributed: February 28, 2019

(With 2 figures)

\begin{abstract}
The southern distribution of the Broad-snouted Caiman (Caiman latirostris Daudin 1802) in Argentina occurs in Santa Fe Province, where its population has been under management by "Proyecto Yacaré" since 1990. From 1997 to 2016 , we captured 77 nesting female Broad-snouted Caimans in Santa Fe Province. Our results suggest that previously defined size classes for Broad-snouted Caiman do not adequately describe the reproductively mature female segment of the population. Here we propose to change size ranges for general size classes for Broad-snouted Caiman. In addition, we have observed that reintroduced reproductive females by Proyecto Yacaré represent about $32 \%$ of captured females. These results indicate that reintroduced females by the management program are surviving and reproducing in the wild at least up to 20 years.
\end{abstract}

Keywords: management, size class, reproduction, sexual maturity.

\section{Tamanho de fêmeas nidificantes do jacaré-de-papo-amarelo (Caiman latirostris Daudin 1802)}

\section{Resumo}

$\mathrm{Na}$ Argentina, a distribuição mais austral do jacaré-de-papo-amarelo (Caiman latirostris Daudin 1802) ocorre na Provincia de Santa Fe, sendo que suas populações são manejadas pelo "Proyecto Yacaré" desde 1990. Entre os anos de 1997 e 2016, nós capturamos 77 fêmeas nidificantes do jacaré-de-papo-amarelo em Santa Fe. Nossos resultados sugerem que as classes de tamanho definidas para o jacaré-de-papo-amarelo não representam a realidade dos animais capturados no presente estudo. Portanto, propõe-se uma alteração nas classes de tamanho para o jacaré-de-papo-amarelo. Nós também observamos que as fêmeas reintroduzidas pelo "Proyecto Yacaré" representaram 32\% das fêmeas capturadas. Estes resultados indicam que fêmeas reintroduzidas pelo programa de manejo estão sobrevivendo e reproduzindo na natureza por, pelo menos, 20 anos.

Palavras-chave: manejo, classe de tamanho, reprodução, maturidade sexual.

\section{Introduction}

The Broad-snouted Caiman (Caiman latirostris) is a medium-sized crocodilian reaching a maximum total length (TL) of $3.5 \mathrm{~m}$, although in some areas within its range, individuals $>2 \mathrm{~m}$ are rare in the wild (Verdade et al., 2010).
However, recent studies of wild Broad-snouted Caiman in coastal areas in Estação Ecológica do Taim (Rio Grande do Sul State, Brazil) revealed that $59 \%$ of captured individuals were $>2 \mathrm{~m}$ (Araújo, 2016). The Broad-snouted Caiman has a 
wide latitudinal distribution in South America (between $5^{\circ} \mathrm{S}$ and $32^{\circ} \mathrm{S}$; Filogonio et al., 2010; Verdade et al., 2010), with the southernmost distribution occurring in Santa Fe province, Argentina ( $31^{\circ} \mathrm{S}$; Simoncini et al., 2009), where populations have been under management by "Proyecto Yacaré” since 1990 (Larriera, 1990). Proyecto Yacaré in Argentina (Larriera et al., 2008), was undertaken to achieve sustainable use of caimans in wetlands in Northern Santa Fe Province. Under this management program, C. latirostris eggs are harvested from wild populations for captive rearing. This management strategy it is based on the concept that eggs can be removed from the wild with minimal impact on the population due to high natural mortality of embryos and hatchlings (Larriera, 2011; Piña et al., 2010; Simoncini et al., 2016). This harvest strategy has already been successfully applied on other species of crocodilians (Webb et al., 1986; Rice et al., 1999; Campos, 2003; Villegas et al., 2017).

Although there are studies on life history parameters of Broad-snouted Caiman, such as sexual dimorphism, sexual maturity, and clutch size (Verdade, 2000, 2001; Larriera et al., 2004, 2006; Simoncini et al., 2009), more information is needed on certain life history traits to develop informed and effective management strategies. For example, knowledge of sexual maturity, particularly the minimum size at which females become reproductively active, is important for understanding caiman population structure and dynamics (Larriera et al., 2006). Caiman populations all over South America were depleted during 1960-1980, mostly due to overharvest of adult females. Current harvesting programs avoid nesting females, and they have proved to be sustainable (Larriera, 2011).

Consequently, having an accurate size range for mature females is valuable information for management. Managers have adopted size classes from Caiman yacare (Daudin 1802) by Ross and Godshalk (2003) for C. latirostris, assuming both species have a similar life history, but so far this has not been tested. For crocodilians, the onset of sexual maturity is related to size and age (Verdade, 1995; Wilkinson and Rhodes, 1997; Wilkinson et al., 2016). The relationship between these two variables is a fundamental feature of the life history of individuals, allowing the estimation of age at sexual maturity and at senescence (Webb and Smith, 1987; Wilkinson and Rhodes, 1997; Wilkinson et al., 2016).

Few data are available regarding the age at first reproduction for the Broad-snouted Caiman. Verdade et al. (2003) reported the earliest onset of sexual maturity in captivity at five years of age, with a snout-vent length (SVL) of $81 \mathrm{~cm}$ and body mass $19.8 \mathrm{~kg}$. In Santa Fe province, the mean SVL of sexual maturity of female Broad-snouted Caimans was reported to be $76 \mathrm{~cm}$ ( 7 reintroduced females) and $89 \mathrm{~cm}$ (7 wild females) (estimated from Larriera et al., 2006). Reintroduced females in this data set were 9-10 years old. More recently, in the same region, wild females $<71 \mathrm{~cm} \mathrm{SVL}$ and $10.5 \mathrm{~kg}$ were observed nesting (Portelinha et al., 2015). Therefore, in this work we test the hypothesis that size ranges of breeding females of C. latirostris exceed the minimum and maximum limits of class III established for C. yacare by Ross and Godshalk
(2003). Our objectives were to determine the size class III including Caiman latirostris nesting females in Santa Fe Province, Argentina, and provide information on the success of the reintroduction of ranched animals into wild populations.

\section{Material and Methods}

This study was conducted in the northern region of Santa Fe Province ( $31^{\circ} 35^{\prime}$ 'S, $60^{\circ} 11^{\prime} \mathrm{W}$, Argentina). Broad-snouted Caiman were reintroduced into wild populations in study sites: Espín, Fisco, Los Saladillos and Lucero (Figure 1); as part of "Proyecto Yacaré" caiman management and conservation initiative. Caimans were released with an individual mark by notching tail scutes indicating release year, so age could be determined if they were recaptured (Larriera et al., 2006; Portelinha et al., 2015). The climate of the region is temperate, with a mean minimum annual temperature of $14.9^{\circ} \mathrm{C}$ and maximum of $25.6^{\circ} \mathrm{C}$ and an annual rainfall of $1.380 \mathrm{~mm}$ (information available in the web site of National Meteorological Service (SMN, 2017). The main habitats and nesting environments of Broad-snouted Caiman in Argentina are characterized as forest, savanna, and floating vegetation (Montini et al., 2006).

From 1997 to 2016, we monitored the caiman nesting areas during reproductive season. Females were caught at their nests in the wild with a steel cable noose and immobilized manually, then sexed by cloacal palpation (Verdade, 1997; Portelinha et al., 2015). We assumed that a female caiman attending a nest was the maternal parent of the clutch in that nest (Amavet et al., 2008). Once caught, we measured TL and SVL (from beginning of snout to beginning of cloaca) with a measuring tape $( \pm 1 \mathrm{~mm})$ and body mass $(\mathrm{BM})$ with a scale $( \pm 0.1 \mathrm{~kg})$. We marked females with an individual identification by notching tail scutes and we released them at the capture site.

\section{Results}

We captured 77 nesting females Broad-snouted Caimans (Table 1), with SVL ranging between $68-98 \mathrm{~cm}$. Four \% of the reproductive female captured were $\leq 70 \mathrm{~cm} \mathrm{SVL}$ and $17 \%$ were $\geq 89.9 \mathrm{~cm}$ SVL (Figure 2).

Since 1990, Proyecto Yacaré in Santa Fe province has been reintroducing Broad-snouted Caiman into wild populations at different sites (Figure 1). Since 2002 to the present, we observed that reintroduced reproductive females represent on average $32 \%$ of captured females (ranging from $22 \%$ in the Espín river to $50 \%$ in the Fisco lagoon). In addition, we recorded one reintroduced female that was 20 years old $(\mathrm{SVL}=80 \mathrm{~cm}$, body mass $=16.6 \mathrm{~kg})$, nesting and attending a nest in Los Saladillos town.

\section{Discussion}

The size classes defined in Ross and Godshalk (2003) for $C$. yacare were Class I: $<25 \mathrm{~cm} \mathrm{SVL}$ (hatchlings of the year); Class II: 25 to $69.9 \mathrm{~cm}$ SVL (juveniles); Class III: 70 to $89.9 \mathrm{~cm} \mathrm{SVL}$ (reproductive male and females); and Class IV: $\geq 90 \mathrm{~cm} \mathrm{SVL}$ (reproductive males). Our study 


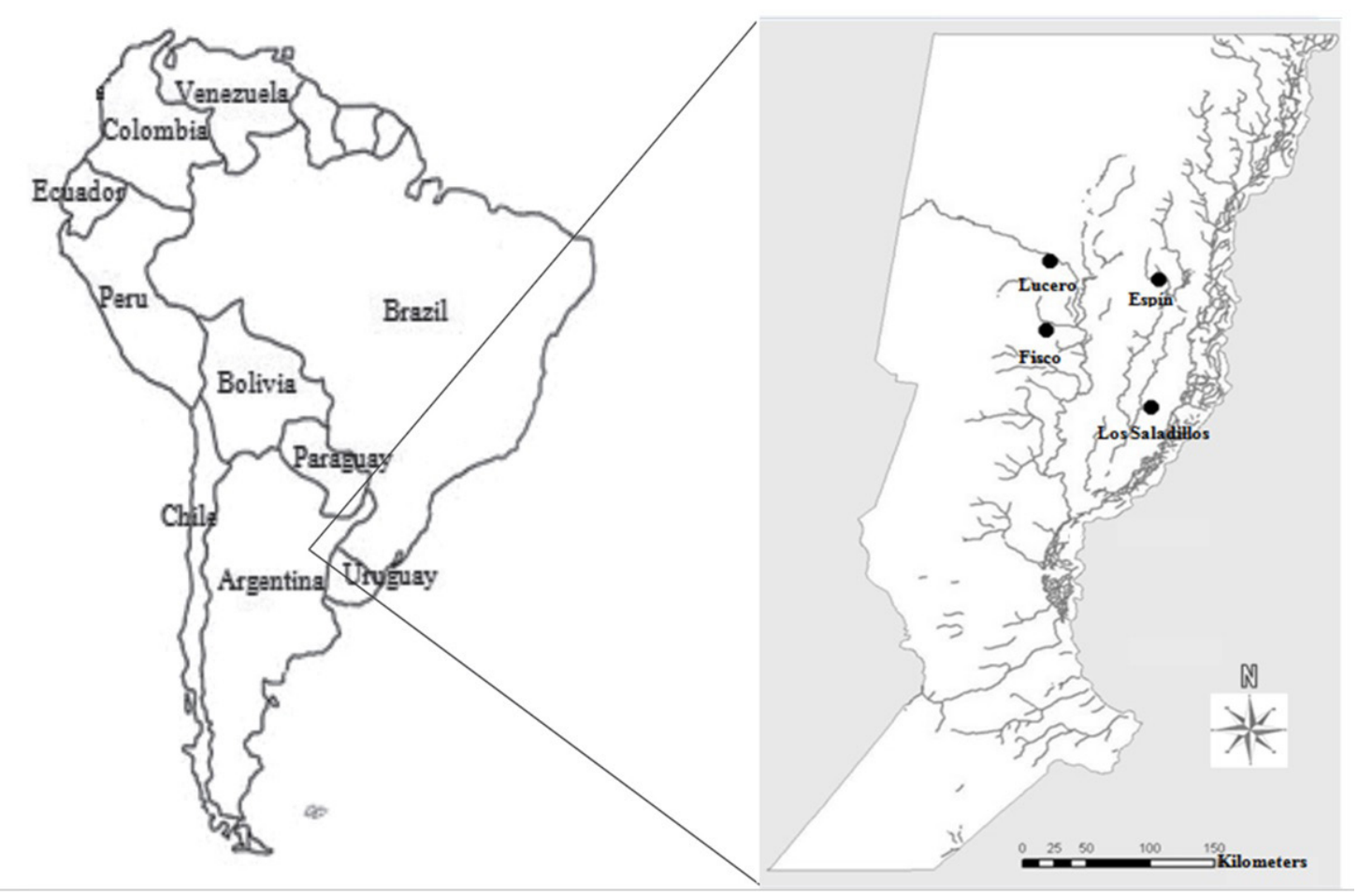

Figure 1. Four study sites where Broad-snouted Caiman were reintroducing into wild populations in Santa Fe Province, Argentina (from Portelinha et al., 2015).

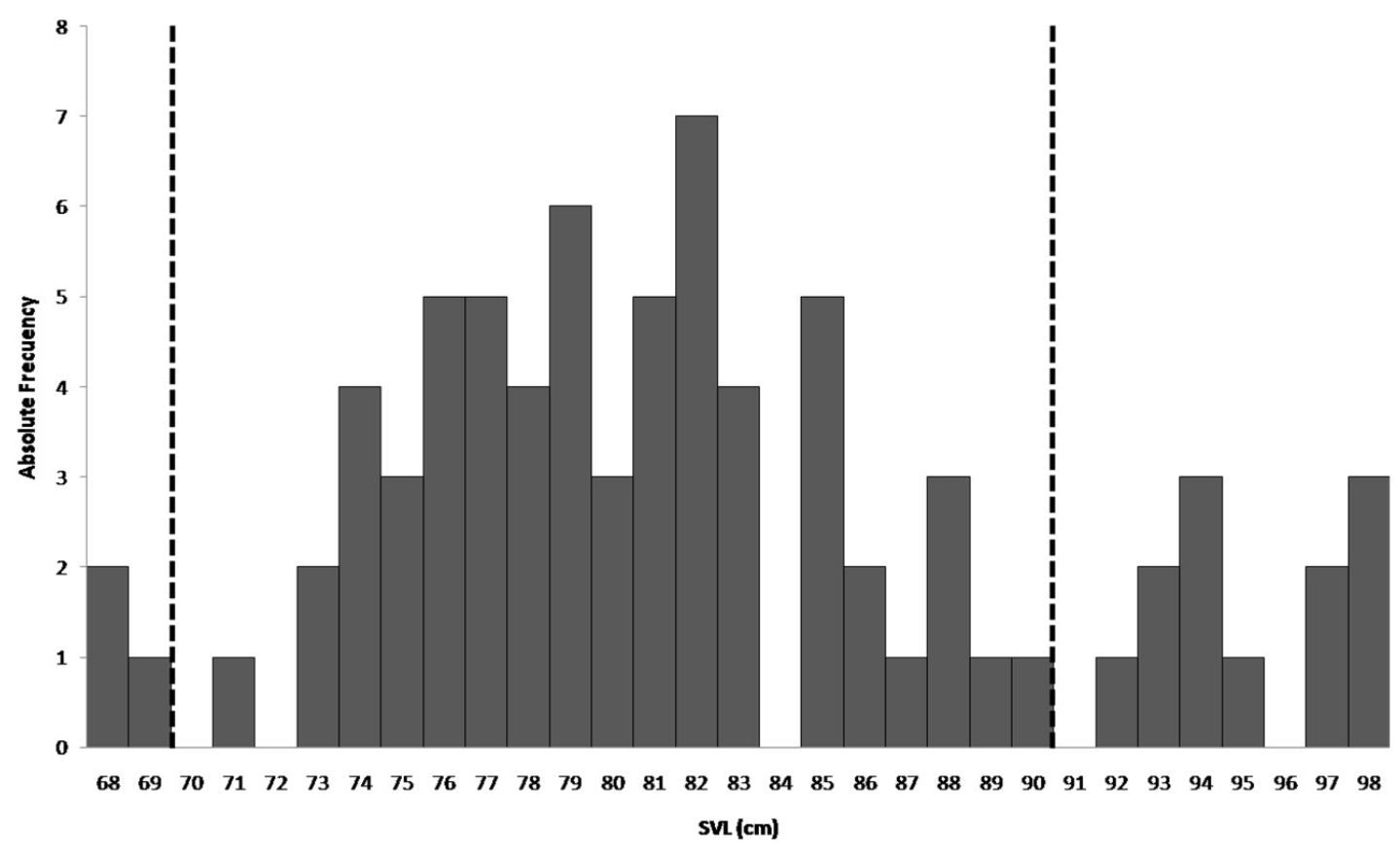

Figure 2. Snout-vent length (SVL) for reproductive female Broad-snouted Caimans captured at their nests in Santa Fe, Argentina from 1998 to 2017. Dotted lines represent the limit of size class III defined by Ross and Godshalk (2003).

indicates that $4 \%$ of the reproductive females captured belong to Class II, $79 \%$ to Class III, and $17 \%$ to Class IV. These results suggest the size classes for Broad-snouted
Caiman, as defined by Ross and Godshalk (2003) do not adequately describe the Broad-snouted Caimans in Santa $\mathrm{Fe}$ Province. Therefore, we propose the following size 
Table 1. Mean Snout Vent Length $(\mathrm{cm}) \pm$ Standard Deviation (SD) and size range $(\mathrm{cm})$ of captured reproductive female Caiman latirostris (wild and reintroduced) in Santa Fe province from 1997 to 2016.

\begin{tabular}{ccccc}
\hline Year & $\begin{array}{c}\text { Wild } \\
(\mathbf{n})\end{array}$ & $\begin{array}{c}\text { Reintroduced } \\
(\mathbf{n})\end{array}$ & $\begin{array}{c}\text { Mean } \pm \text { SD } \\
(\mathbf{c m})\end{array}$ & $\begin{array}{c}\text { Range } \\
(\mathbf{c m})\end{array}$ \\
\hline 1997 & 3 & 0 & $80.3 \pm 1.2$ & $79-81$ \\
2001 & 10 & 3 & $83.4 \pm 9.1$ & $74-98$ \\
2003 & 2 & 1 & $76 \pm 1.7$ & $75-78$ \\
2004 & 6 & 0 & $83.8 \pm 5.7$ & $71-94$ \\
2005 & 6 & 2 & $81.1 \pm 7.6$ & $73-96$ \\
2006 & 3 & 0 & $90 \pm 4.6$ & $85-94$ \\
2007 & 5 & 1 & $86 \pm 8.7$ & $73-97$ \\
2009 & 1 & 0 & $68 \pm 0$ & 68 \\
2010 & 11 & 7 & $79.2 \pm 4.3$ & $68-86.5$ \\
2011 & 2 & 0 & $79 \pm 0$ & 79 \\
2013 & 3 & 1 & $85.5 \pm 4$ & $80-89$ \\
2014 & 3 & 1 & $84.3 \pm 7.8$ & $75-94$ \\
2015 & 4 & 0 & $79.5 \pm 6.8$ & $71-87$ \\
2016 & 2 & 0 & $89.5 \pm 10.6$ & $82-97$ \\
Total & 61 & 16 & & $68-96$ \\
\hline
\end{tabular}

classes: Class I: $<25 \mathrm{~cm}$ SVL; Class II: 25 to $67.9 \mathrm{~cm} \mathrm{SVL}$; Class III: 68 to $99.9 \mathrm{~cm} \mathrm{SVL}$; and Class IV: $\geq 99.9 \mathrm{~cm} \mathrm{SVL}$. By using these new size classes, it is possible to avoid the inclusion of reproductive females in Class II. Class III will include the range of reproductive females and some (smaller) reproductive males, and finally Class IV will only include large (reproductive) males. These size classes should be compared among Broad-snouted Caiman populations from temperate and tropical areas throughout its range to examine differences and potential climatic influences on minimum size or age of maturation.

Broad-snouted Caimans produced by eggs harvested from the wild and reared as part of the Proyecto Yacaré ranching program are reintroduced into the wild at about nine months of age. Because they stay in a greenhouse and have food ad libitum, those caimans grow faster than wild caimans during the captivity period (reaching about $50 \mathrm{~cm}$ total length when reintroduced, whereas wild ones of the same age are about $25-27 \mathrm{~cm}$ ). So, reintroduction occurs, when they almost attain size class II (Ross and Godshalk, 2003), at the same nest sites were the eggs were harvested. Reintroduced animals also present higher survivorship than wild animals of the same cohort, since survivorship in crocodilians is size related (Rootes, 1989; Elsey et al., 1992). These size differences between wild and reintroduced animals are expected to exist for a few years. We speculate that reintroduced females could nest for the first time at younger age than wild ones, since Verdade (1995) indicated that there are two conditions to nest, a minimum size, and a minimum age.

Data from our study has many implications for Broad-snouted Caiman management. First, the presence of marked nesting females reintroduced for the program is evidence that reintroduced young caiman grow and reach adult size, reproduce in the wild, and keep nesting for up to 20 years (the oldest marked female captured in this work, and possibly one of the first cohorts released by Proyecto Yacaré). Second, if there is a hunting program in the future, information on the minimum and maximum size of the nesting females is crucial in order to minimize removing nesting females from the population. Finally, application of size-dependent fertility in population models will allow managers to gain knowledge about the contribution of different size classes to population growth, which is important when exploring management options. Finally, but not least important, to know the size of the nesting females is useful for monitoring the effects of caiman management actions.

\section{Acknowledgements}

We thank other members of Proyecto Yacaré. This study was supported by Proyecto Yacaré, Yacaré Santafesinos (Gob. Prov. Santa Fe/MUPCN), PFIP 2008; and PICT 2014 N2138 (to C. Piña), PICT 2014 N2212 (to M. Simoncini) CAID 2013 PI 5012022010022LI (to A. Larriera). We appreciate comments and suggestions of the manuscript by T.R. Rainwater and A.R. Woodward. This is the publication 99 from Proyecto Yacaré.

\section{References}

AMAVET, P., ROSSO, E., MARKARIANI, R. and PIÑA, C.I., 2008. Microsatellite DNA markers applied to detection of multiple paternity in Caiman latirostris in Santa Fe, Argentina. Journal Experimental Zoology A, vol. 309, no. 10, pp. 637-642. http://dx.doi.org/10.1002/jez.496. PMid:18777523.

ARAUJO, D.D., 2016. Relações tróficas e seleção de microambiente de forrageio pelo Jacaré-de-papo-amarelo, Caiman latirostris (Daudin, 1802), em banhados subtropicais brasileiros. São Leopoldo: Universidade do Vale do Rio dos Sinos, 63 p. Dissertação de Mestrado.

CAMPOS, Z.D.S., 2003. Efeito do habitat na fecundidade das fêmeas, sobrevivência e razão sexual dos jovens de jacarés-dopantanal. Corumbá: Embrapa Pantanal, 22 p. Boletim de Pesquisa e Desenvolvimento.

ELSEY, R.M., JOANEN, T., MCNEASE, L. and KINLER, N., 1992. Growth rates and body condition factors of Alligator mississippiensis in coastal Louisiana wetlands: a comparison of wild and farm-released juveniles. Comparative Biochemistry and Physiology Part A: Physiology, vol. 103, no. 4, pp. 667-672. http://dx.doi.org/10.1016/0300-9629(92)90164-L.

FILOGONIO, R., ASSIS, V.B., PASSOS, L.F. and COUTINHO, M.E., 2010. Distribution of populations of broad-snouted caiman (Caiman latirostris, Daudin 1802, Alligatoridae) in the São Francisco River basin, Brazil. Brazilian Journal of Biology $=$ Revista Brasileira de Biologia, vol. 70, no. 4, pp. 961-968. http:// dx.doi.org/10.1590/S1519-69842010000500007. PMid:21180900.

LARRIERA, A., 1990. A program of monitoring and recovering of caimans populations in Argentina with the aim of management. In: Crocodiles. Proceedings of the 10th Working Meeting of the IUCN-SSC Crocodile Specialist Group, 1990, Gland. Gland: IUCN, pp. 1-5. 
LARRIERA, A., 2011. Ranching the broad-snouted caiman (Caiman latirostris) in Argentina: an economic incentive for wetland conservation by local inhabitants In: M. ABENSPERGTRAUN, D. ROE and C. O'CRIODAIN, eds. CITES and CBNRM proceedings of an international symposium "the relevance of CBNRM to the conservation and sustainable use of CITES-listed species in exporting countries. Gland: IUCN, $172 \mathrm{p}$.

LARRIERA, A., IMHOF, A. and SIROSKI, P., 2008. Estado actual de los programas de conservación y manejo de género Caiman en Argentina. In: J. CASTROVIEJO, J. AYARZAGUENA and A. VELASCO, eds. Contribución al conocimiento del género Caiman de Sudamérica. Sevilla: Asociación Amigos de Doñana, pp. 141180. Publicaciones de la Asociación Amigos de Doñana, no. 18.

LARRIERA, A., PIÑA, C.I., SIROSKI, P. and VERDADE, L.M., 2004. Allometry of reproduction in wild broad-snouted caimans (Caiman latirostris). Journal of Herpetology, vol. 38, no. 2, pp. 301-304. http://dx.doi.org/10.1670/145-03A.

LARRIERA, A., SIROSKI, P., PIÑA, C.I. and IMHOF, A., 2006. Sexual maturity of farm-released Caiman latirostris (Crocodylia: Alligatoridae) in the wild. Herpetological Review, vol. 37 , pp. 26-28.

MONTINI, J.P., PIÑA, C.I., LARRIERA, A., SIROSKI, P. and VERDADE, L.M., 2006. The relationship between nesting habitat and hatching success in Caiman latirostris (Crocodylia, Alligatoridae). Phyllomedusa, vol. 5, no. 2, pp. 91-96. http:// dx.doi.org/10.11606/issn.2316-9079.v5i2p91-96.

PIÑA, C.I., SIROSKI, P., PRINCIPE, G. and SIMONCINI, M., 2010 [viewed 1 June 2017]. Populations Status of Caiman yacare and Caiman latirostris in North Argentina [online]. Australia: IUCN-SSC Crocodile Specialist Group, pp. 1-5. Available from: www.iucnesg.org/ph1/modules/Journal/

PORTELINHA, T.C.G., JAHN, G.A., HAPON, M.B., VERDADE, L.M. and PIÑA, C.I., 2015. Hormone levels and ultrasound evaluation of Caiman latirostris (Crocodylia, Alligatoridae) ovulation. South American Journal of Herpetology, vol. 10, no. 1, pp. 23-31. http://dx.doi.org/10.2994/SAJH-D-14-00030.1.

RICE, K.G., PERCIVAL, H.F., WOODWARD, A.R. and JENNINGS, M.L., 1999. Effects of egg and hatchling harvest on American Alligators in Florida. The Journal of Wildlife Management, vol. 63, no. 4, pp. 1193-1200. http://dx.doi.org/10.2307/3802837.

ROOTES, W.L., 1989. Behavior of the American alligator in a Louisiana freshwater marsh. Louisiana: Louisiana State University, 107 p. Ph.D. Dissertation.

ROSS, J.P. and GODSHALK, R., 2003. Taller internacional para el manejo y comercio de Caiman yacare. Gainsville: Florida Museum of Natural History, $85 \mathrm{p}$.

SIMONCINI, M.S., MARCÓ, M.V.P., PORTELINHA, T.C.G. and PIÑA, C.I., 2016. Evaluation of factors associated with predation on Caiman latirostris nests (Crocodylia: Alligatoridae) in Argentina. Phyllomedusa, vol. 15, no. 2, pp. 137-146. http:// dx.doi.org/10.11606/issn.2316-9079.v15i2p137-146.

SIMONCINI, M.S., PIÑA, C.I. and SIROSKI, P., 2009. Clutch size of Caiman latirostris (Crocodylia: Alligatoridae) varies on a latitudinal gradient. North-Western Journal of Zoology, vol. 5, pp. 191.
SERVICIO METEOROLÓGICO NACIONAL - SMN, 2017 [viewed 19 January 2017]. Available from: www.smn.gob.ar

VERDADE, L.M., 1995. Biología reproductiva do jacaré-depapo-amarelo (Caiman latirostris) em São Paulo, Brasil. In: A. LARRIERA and L.M. VERDADE, eds. La conservación y el manejo de caimanes y cocodrilos en América Latina. Santo Tomé: Fundación Banco Bica, pp. 57-74.

VERDADE, L.M., 1997. Morphometric analysis of the Broadsnouted caiman (Caiman latirostris): an assessment of individual clutch, body size, sex, age, and area of origin. Gainesville: University of Florida, 174 p. PhD Thesis.

VERDADE, L.M., 2000. Regression equations between body and head measurements in the broad-snouted caiman (Caiman latirostris). Revista Brasileira de Biologia, vol. 60, no. 3, pp. 469-482. http://dx.doi.org/10.1590/S0034-71082000000300012. PMid:11188873.

VERDADE, L.M., 2001. Allometry of reproduction in broadsnouted caiman (Caiman latirostris). Brazilian Journal of Biology = Revista Brasileira de Biologia, vol. 61, no. 3, pp. 431-435. http:// dx.doi.org/10.1590/S1519-69842001000300012. PMid:11706570.

VERDADE, L.M., LARRIERA, A. and PIÑA, C.I., 2010. Broad-snouted Caiman Caiman latirostris. In: S.C. MANOLIS and C. STEVENSON, eds. Crocodiles: status survey and conservation action plan. $3 \mathrm{rd}$ ed. Australia: Crocodile Specialist Group, IUCN, pp. 18-22.

VERDADE, L.M., SARKIS-GONÇALVES, F., MIRANDAVILELA, M.P. and BASSETTI, L.A.B., 2003. Caiman latirostris (Broad-snouted Caiman) new record of age at sexual maturity in captivity. Herpetological Review, vol. 34, pp. 225-226.

VILLEGAS, A., MENDOZA, G.D., ARCOS-GARCÍA, J.L. and REYNOSO, V.H., 2017. Nesting of Morelet's crocodile, Crocodylus moreletii (Dumeril and Bibron), in Los Tuxtlas, Mexico. Brazilian Journal of Biology $=$ Revista Brasileira de Biologia, vol. 77, no. 4, pp. 724-730. http://dx.doi.org/10.1590/15196984.19015. PMid:28355391.

WEBB, G.J.W. and SMITH, A.M.A., 1987. Life history parameters, population dynamics and the management of crocodilians. In: G.J.W. WEBB, S.C. MANOLIS and P.J. WHITEHEAD, eds. Wildife management: crocodiles and alligators. Australia: Surrey Beatty \& Sons, pp. 199-210.

WEBB, G.J.W., BAYLISS, P.G. and MANOLIS, S.C., 1986. Population research on crocodiles in the Northern Territory. In: Crocodiles. Proceedings of the 8th Working Meeting of the IUCN-SSC Crocodile Specialist Group, 1986, Quito, Ecuador. Gland: IUCN, pp. 22-31.

WILKINSON, P.M. and RHODES, W.E., 1997. Growth rates of American alligators in coastal South Carolina. The Journal of Wildlife Management, vol. 61, no. 2, pp. 397-402. http://dx.doi. org/10.2307/3802596.

WILKINSON, P.M., RAINWATER, T.R., WOODWARD, A.R., LEONE, E.H. and CARTER, C., 2016. Determinate growth and reproductive lifespan in the American alligator (Alligator mississippiensis): evidence from long-term recaptures. Copeia, vol. 104, no. 4, pp. 843-852. http://dx.doi.org/10.1643/CH-16-430. 